\title{
SDHA Positive
}

National Cancer Institute

\section{Source}

National Cancer Institute. SDHA Positive. NCI Thesaurus. Code C160573.

An indication that expression of SDHA has been detected in a sample. 